\title{
Polymorphism in spring and winter rapeseed varieties (Brassica napus L.) identified by SSR markers
}

\author{
0. L. Klyachenko ${ }^{1}$, L. M. Prysiazhniuk ${ }^{2 *}$, N. V. Shofolova ${ }^{1}$, 0. V. Piskova ${ }^{2}$ \\ ${ }^{1}$ National University of Life and Environmental Sciences of Ukraine, Heroiv Oborony St., 15, 03041, Kyiv, Ukraine \\ ${ }^{2}$ Ukrainian Institute for Plant Variety Examination, 15 Henerala Rodymtseva St., 03041, Kyiv, Ukraine, \\ "e-mail: prysiazhniuk_l@ukr.net
}

Purpose. To assess the genetic diversity of rapeseed varieties using SSR markers in order to create breeding material and use that material in complex in vitro selection for drought and salt tolerance. Methods. PCR analysis, cluster analysis. Results. The results of analysis of rapeseed varieties polymorphism based on molecular-genetic markers is presented. As a result of the analysis of rapeseed varieties, 41 alleles were detected using the studied markers, that is, an average of 10.3 alleles per marker. The number of polymorphic loci identified by four microsatellite markers (Ra3-H09, Na12-A02, FIT0063 and $\mathrm{Na10-B07)}$ was 24. The polymorphism level of the studied varieties was $51 \%$ on average and varied between $33 \%$ (identified by FITO-063) and 87\% (identified by Na12-A02). According to the frequency distribution of the obtained alleles, the highest frequency by SSR marker Ra3-H09 had a 117 bp allele identified in three varieties: 'Senator Liuks', 'Danhal' and 'Chornyi Veleten'. It was found that the unique alleles identified by Ra3-H09 were the alleles at a frequency of 0.06 and size of $135 \mathrm{bp}$ (variety 'Aliot') and $156 \mathrm{bp}$ (variety 'Kliff'). FIT0-063 marker identified the smallest number of alleles (5) at a frequency distribution ranging from 0.11 to 0.33 . The unique alleles identified by FIT0-063 marker were the ones at a frequency of 0.1 and size of 258 bp (variety 'Geros') and 273 bp (variety 'Chornyi Veleten'). The maximum number of alleles was obtained using Na12-A02 marker. The distribution showed the highest frequency (0.11) for the 158 bp and 192 bp alleles. Using Na10-B07 marker, three alleles were identified at a frequency of 0.04. These 144, 156 and 194-bp alleles were found in varieties 'Kliff', 'Geros' and 'Nelson'. Cluster analysis revealed four variety clusters: 'Senator Liuks' and 'Danhal', 'NK Technik' and 'NK Petrol', 'Geros' and 'Aliot', 'Kliff' and 'Nelson'. 'Chornyi Veleten' variety did not enter any cluster. The most distant varieties are 'Kliff' and 'Nelson' with a genetic distance value of 3.32. Foreign varieties 'NK Technik' and 'NEC Petrol' with the value of genetic distances between them equal 1.41 appeared to be the most similar by the four studied SSR markers. 0ther varieties differed by at least one marker. Conclusions. Consequently, using the set of four microsatellite markers provides an assessment of rapeseed varietal diversity that can be used in complex in vitro selection for drought and salt tolerance.

Keywords: varietal diversity; rapeseed; microsatellite markers; cluster analysis.

\section{Introduction}

Rapeseed (Brassica napus L.) is one of the most important high-yielding industrial crops promising for export and production of rapeseed oil and biodiesel for the domestic market [1-3]. The crop productivity can be increased through creating new hybrids with a better tolerance to environmental changes.

\footnotetext{
Larysa Prysiazhniuk

http://orcid.org/0000-0003-4388-0485

Oksana Klyachenko

https://orcid.org/0000-0002-4087-4082

Natalia Shofolova

https://orcid.org/0000-0003-3207-0110

Oksana Piskova

https://orcid.org/0000-0003-3650-2101
}

The constantly growing area of saline lands, which now, according to FAO, exceeds $7 \%$ of the world's agricultural land [4-5] along with climate change, requires research aimed at creating hybrids of complex tolerance to adverse abiotic factors.

The efficiency of breeding is largely determined by the genetic diversity of the parent material; consequently, it is necessary to search and introduce new approaches to increasing the genetic heterogeneity of the selection material [6-7]. Such approaches include cell, tissue, plant organ culture and using DNA-markers for identification of the selection material [8-10].

Genotyping technology based on DNA polymorphism is used for both cultural and wild species of the genus Brassica L. DNA makers have many advantages. The molecular markers 
are not subjected to environmental change, which makes them particularly informative and superior to traditional methods [11].

Various DNA markers have been successfully used to study genetic diversity in Brassica, such as random amplified polymorphic DNA (RAPD), restriction fragment length polymorphism (RFLP), amplified fragment length polymorphism (AFLP), sequence-related amplified polymorphism (SRAP), simple sequence repeat (SSR), single-nucleotide polymorphisms (SNP) [12]. SSR analysis allows distinguishing genera, species and varieties, revealing genetic heterogeneity of breeding material, and controlling genetic material introgression from parents [13-15]. The technology of genotyping based on SSR markers allows identifying genetic diversity of rapeseed varieties and genetic homogeneity of breeding material, selecting parents for crosses and controlling trans- fer of genetic material from parents to hybrids [7, 16-18].

The goal of this research was to assess the genetic diversity of rapeseed varieties using SSR markers in order to create breeding material and use that material in complex in vitro selection for drought and salt tolerance.

\section{Materials and methods}

Characteristics of the investigated material

The material for the study was nine varieties of winter and spring rapeseed of Ukrainian ('Senator Liuks', 'Danhal', 'Chornyi Veleten' and 'Aliot') and foreign origin ('NK Technik', 'Necropolis', 'Kliff', 'Geros', 'Nelson') promising for the creation of drought and salt-resistant lines. All the varieties have been listed in the State Register of Varieties Suitable for Distribution in Ukraine from 2001 to 2011 as shown in Table 1.

Characteristics of varieties of winter and spring rapeseed

Table 1

\begin{tabular}{|l|c|l|}
\hline $\begin{array}{c}\text { Name } \\
\text { of variety }\end{array}$ & $\begin{array}{c}\text { Year } \\
\text { of registration }\end{array}$ & \multicolumn{1}{c|}{ Applicant } \\
\hline \multicolumn{3}{|c|}{ Winter varieties } \\
\hline 'Senator Liuks' & 2006 & National Research Centre Institute of Agriculture Ukrainian Academy of Agrarian Sciences \\
\hline 'NK Technik' & 2011 & Syngenta Seeds S.A.S. \\
\hline 'NK Petrol' & 2011 & Syngenta Seeds S.A.S. \\
\hline ‘Danhal' & 2001 & $\begin{array}{l}\text { Ivano-Frankivsk Institute of Agroindustrial Production Ukrainian Academy of Agrarian } \\
\text { Sciences }\end{array}$ \\
\hline \begin{tabular}{l|l|l|} 
'Nelson' \\
'Chornyi \\
Veleten'
\end{tabular} & 2008 & Syngenta Seeds S.A.S. \\
\hline 'Aliot' & 2002 & Institute of Fodder and Agriculture of Podillia Ukrainian Academy of Agrarian Sciences \\
\hline \multicolumn{2}{|l|}{} \\
\hline 'Kliff' & 2003 & $\begin{array}{l}\text { National University of Life and Environmental Sciences of Ukraine; Sytnik I. D.; } \\
\text { Kolodii Yu. A. }\end{array}$ \\
\hline ‘Geros' & 2006 & Rorddeutsche Pflanzenzucht Hans-Georg Lembke KG \\
\hline
\end{tabular}

The research was carried out at the Ukrainian Institute for Plant Varieties Examination (Kyiv, Ukraine) in collaboration with the National University of Life and Environmental Sciences of Ukraine (Kyiv, Ukraine) in $2017 / 2018$.

\section{Isolation of DNA and PCR}

The material was provided by the National University of Life and Environmental Sciences of Ukraine (The Problem Laboratory Of Phytovirology and Biotechnology) where the selection in vitro for drought and salt tolerance was carried out. DNA was isolated from the leaves of obtained in vitro rapeseed plants using cationic detergent CTAB (cetyltrimethylammonium bromide). Chloroformisoamyl alcohol and ethanol solution were used in double purification of the mixture [19-21].
PCR (polymerase chain reaction) was used to investigate the molecular and genetic polymorphism of rapeseed varieties. For this purpose, we used four specific primers for four microsatellite loci (MS-loci): Ra3-H09, Na12-A02, FITO-063 and Na10-B07 as shown Table 2.

The primers were chosen based on their ability to differentiate genotypes and PIC [11, 2124]. The PCR was performed using BioRad IQ5 (USA). The reaction mixture $(20 \mu \mathrm{L})$ contained $100 \mathrm{ng}$ of total plant DNA, buffer $(10 \mathrm{mM}$ Tris$\mathrm{HCl}, \mathrm{pH} 9.0,50 \mathrm{mM} \mathrm{KCl}, 0.01 \%$ Triton X-100, $2.5 \mathrm{mM} \mathrm{MgCl}_{2}$ ), $200 \mu \mathrm{M}$ deoxynucleoside triphosphates mix (dNTPs), $0.2 \mu \mathrm{M}$ of each primer and 1 unit of Taq polymerase (Thermo Fisher Scientific, USA). The amplification parameters for the examined rapeseed markers were set as follows: initial denaturation $\left(94^{\circ} \mathrm{C}\right)$ 5 min, 35 cycles; denaturation $\left(94{ }^{\circ} \mathrm{C}\right) 45 \mathrm{~s}$; 
Characteristics of SSR-loci primers of rapeseed

Table 2

\begin{tabular}{|c|c|c|c|c|}
\hline Primer & $\begin{array}{c}\text { The nucleotide sequence } \\
\text { of primers } 5^{\prime} \ldots 3^{\prime}\end{array}$ & Motif & $\begin{array}{l}\text { Hybridization } \\
\text { temperature }\left({ }^{\circ} \mathrm{C}\right)\end{array}$ & $\begin{array}{l}\text { Expected size of amplicones } \\
\text { (bp) }\end{array}$ \\
\hline \multirow{2}{*}{ Ra3-H09 } & F-gtggtaacgacggtccattc & \multirow{2}{*}{$(\mathrm{TGG})_{3}$} & \multirow{2}{*}{53.6} & \multirow{2}{*}{$119-129$} \\
\hline & R - accacgacgaagactcatcc & & & \\
\hline \multirow{2}{*}{ Na12-A02 } & F- agccttgttgcttttcaacg & \multirow{2}{*}{$(\mathrm{CT})_{16}$} & \multirow{2}{*}{54.0} & \multirow{2}{*}{$161-202$} \\
\hline & $\mathrm{R}$ - agtgaatcgatgatctcgcc & & & \\
\hline \multirow{2}{*}{ FITO-063 } & F-gttcagttcccagattcctaa & \multirow{2}{*}{$(\mathrm{CCG})_{15}$} & \multirow{2}{*}{49.0} & \multirow{2}{*}{$267-700$} \\
\hline & $\mathrm{R}-$ tttcctcttccttctctcttc & & & \\
\hline \multirow{2}{*}{ Na10-B07 } & F-gccttagattagatggtcgcc & \multirow{2}{*}{$(\mathrm{CT})_{29}$} & \multirow{2}{*}{53.0} & \multirow{2}{*}{$174-213$} \\
\hline & $\mathrm{R}$ - acttcagctccgatttgcc & & & \\
\hline
\end{tabular}

annealing $\left(49-54{ }^{\circ} \mathrm{C}\right) 45 \mathrm{~s}$; synthesis $\left(72{ }^{\circ} \mathrm{C}\right)$ $1 \mathrm{~min}$; final elongation $\left(72{ }^{\circ} \mathrm{C}\right) 10 \mathrm{~min}$.

Visualization of amplifications and cluster analysis

After amplification, the reaction products were visualized by electrophoresis in a $2 \%$ agarose gel in $0.5 \times$ TBE (tris-borate buffer solution) [25]. DNA electrophoresis was carried out for 1 hour at an electric field intensity of $5 \mathrm{~V} / \mathrm{cm}$.

After the completion the electrophoresis, based on the obtained data a matrix was constructed, where the presence / absence of a certain amplicon was designated as $1 / 0$, respectively.
The method of hierarchical clustering with Euclidean distance and STATISTICA 12.0 (Trial version) were exploited to analyse the obtained research data [26-27].

\section{Results and discussion}

Determination of polymorphism in rapeseed varieties by SSR markers

Alleles of the expected size were obtained by PCR on four SSR markers with specific primers. The amplicons were obtained by markers Na12-A02 (the most polymorphic loci) and FITO-063 (the lowest level polymorphism) and are shown Figures 1 a, b.
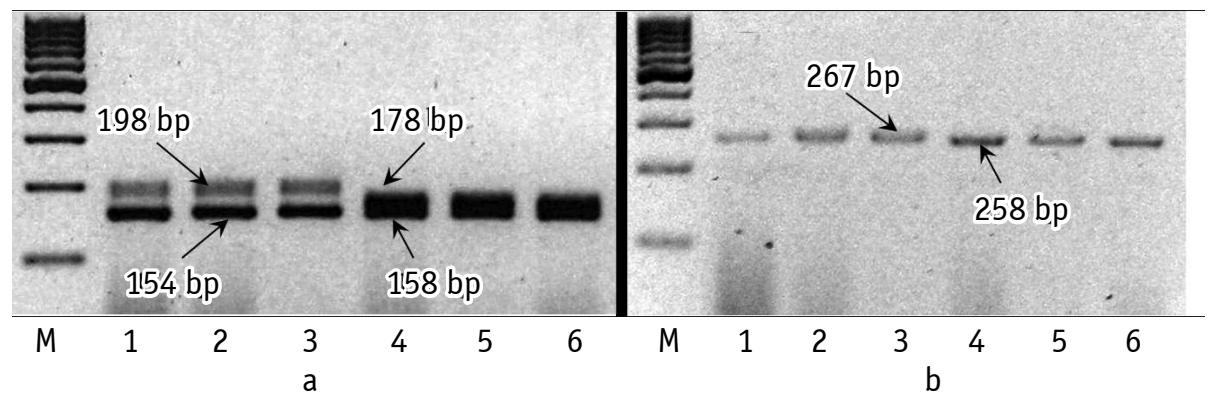

Fig. 1. Electropherogram of DNA amplification products of different rapeseed varieties: $M$ - molecular weight marker 100 bp DNA Ladder O'GeneRuler (Thermo Scientific); (a) based on Na12-A02 marker: 1-3 genotypes of 'Kliff' variety, 4-6 genotypes of 'Geros' variety; (b) based on FIT0-063 marker: 1-3 genotypes of 'Kliff' variety, 4-6 genotypes of 'Geros' variety

As a result of PCR the Kliff' variety by primer Na12-A02 marker, amplicons of $198 \mathrm{bp}$ and $154 \mathrm{bp}$ were found. The amplification products of 'Geros' variety were $178 \mathrm{bp}$ and $158 \mathrm{bp}$. In general two alleles of different size were identified for all studied varieties by Na12-A02 marker. Using FITO-063 marker five alleles were obtained for nine varieties. Figure $1 \mathrm{~b}$ illustrates that the allele $267 \mathrm{bp}$ was identified in 'Kliff' variety. Allele 258 bp was found 'Geros' variety by FITO-063 marker. It should be mentioned that the allele $267 \mathrm{bp}$ was identified also in 'Aliot' and 'Nelson' varieties.

Resulting from analysis of the rapeseed varieties by the investigated markers 41 alleles were detected, i.e. on the average of 10.3 alleles per marker as shown Table 3.
Table 3

Analysis of the level of polymorphism with SSR markers

\begin{tabular}{|l|c|c|c|}
\hline \multicolumn{1}{|c|}{ Primer } & $\begin{array}{c}\text { Total } \\
\text { alleles }\end{array}$ & $\begin{array}{c}\text { Polymorphic } \\
\text { alleles }\end{array}$ & $\begin{array}{c}\text { Polymorphism level* } \\
(\%)\end{array}$ \\
\hline Ra3-H09 & 11 & 5 & 45 \\
Na12-A02 & 16 & 14 & 87 \\
FIT0-063 & 5 & 2 & 33 \\
Na10-B07 & 9 & 3 & 40 \\
\hline
\end{tabular}

*Polymorphism level $=$ (number of polymorphic bands/ number of total bands) $\times 100 \%$

The total number of polymorphic loci was 24 and varied from 2 to 14 by markers. The polymorphism level for the varieties under study was $51 \%$. The highest level of polymorphism (87\%) was marked by Na12-A02 marker and the lowest $(33 \%)$ by FITO-063. A slightly lower level of polymorphism $(40 \%)$ was obtained by $\mathrm{Li}$ and co-authors [11] in the study of 16 rape- 
seed varieties. Hasan et al. [16], 2006 used combinations of 30 SSR-primers, which included the primer groups $\mathrm{Ra} 3$ and $\mathrm{Na} 12$, to estimate genetic diversity of rapeseed varieties. They obtained 51 polymorphic loci of (out of 220) for 96 genotypes. Polymorphic loci demonstrated unique allele sizes for all 96 genotypes.
Tommasini et al. [30] obtained a high level of polymorphism (68\%) for the primer Na12-A02 2003. The researchers suggested the use of a set of 15 SSR-primers for use in the DUS-test.

We determined the frequencies of identified alleles for each marker under study as shown Figures 2 a, b; 3 a, b.
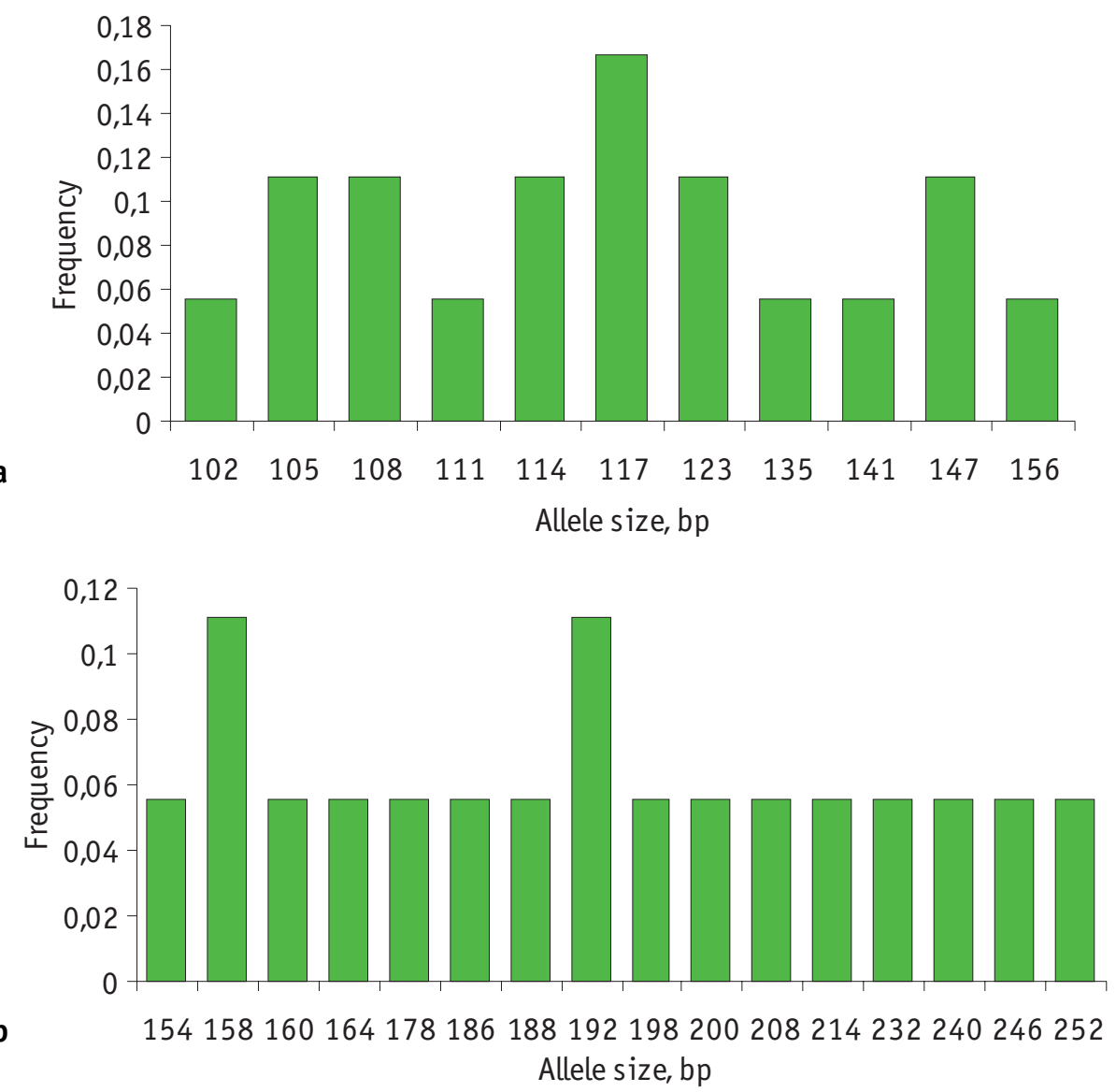

Fig. 2. Distribution of allele frequencies detected by markers (a) Ra3-H09 and (b) Na12-A02

The distribution showed that the highest frequency by SSR marker Ra3-H09 had a $117 \mathrm{bp}$ allele identified in three varieties: 'Senator Liuks', 'Danhal' and 'Chornyi Veleten'. The unique alleles at a frequency of 0.06 were found in 'Aliot' variety (135 bp) and 'Kliff' variety (156 bp). The biggest number of alleles was obtained using Na12-A02 marker. The distribution showed the highest frequency $(0.11)$ for the $158 \mathrm{bp}$ and $192 \mathrm{bp}$ alleles. An allele of $158 \mathrm{bp}$ was detected in 'Geros' and 'Nelson' varieties and another allele of $192 \mathrm{bp}$ was identified in 'NK Technik' and 'NK Petrol'. Other detected alleles had a frequency of 0.06 .

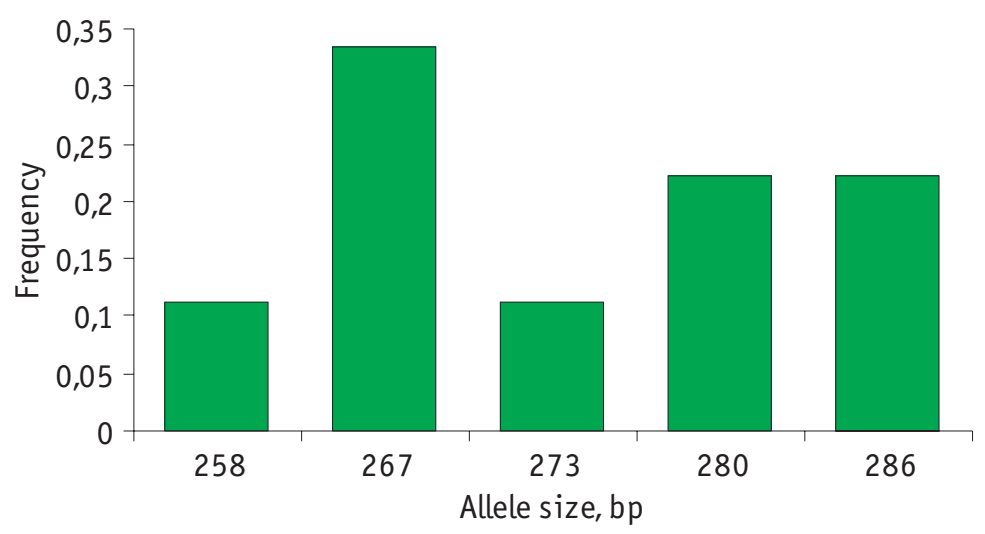




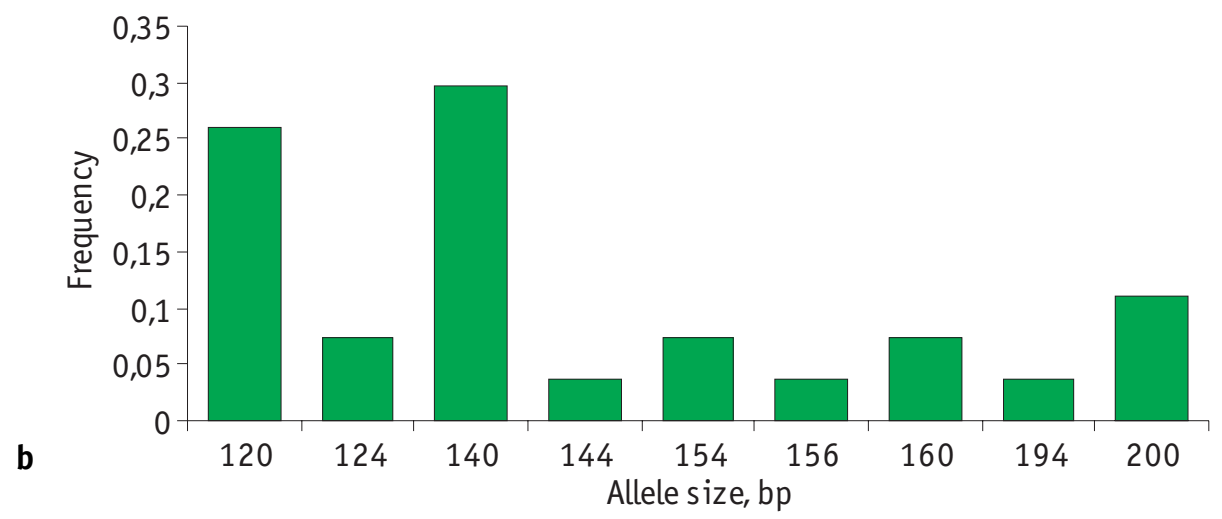

Fig. 3. Distribution of allele frequencies detected by markers (a) FIT0-063 and (b) Na10-B07

FITO-063 marker identified the smallest number of alleles (5) at a frequency distribution ranging from 0.11 to 0.33 . The $258 \mathrm{bp}$ and 273 bp alleles at a frequency of 0.11 were unique. The specified alleles were identified in 'Geros' and 'Chornyi Veleten' varieties, respectively. Na10-B07 marker detected three alleles at a frequency of 0.04: 144, 156 and $194 \mathrm{bp}$, in 'Kliff', 'Geros' and 'Nelson' varieties, respectively.

Thus, it was found that 'Geros', 'Kliff', 'Aliot' and 'Chornyi Veleten' had the unique alleles, while 'Nelson' differed by Na10-B07 marker. It was found that the studied rapeseed varieties differed by at least one marker.

\section{Cluster analysis of rapeseed varieties}

To find out the similarity of rapeseed varieties, we carried out cluster analysis of the matrix of the presence/absence of identified alleles. The method of unweighted pair-group average was used to divide the genotypes under investigation into clusters. The average value of genetic proximity between the members of a cluster and a candidate for inclusion in the cluster was the criterion for determining the degree of similarity [28-29]. Shown in Figure 4 are the clustering results, presented as a phylogenetic tree.

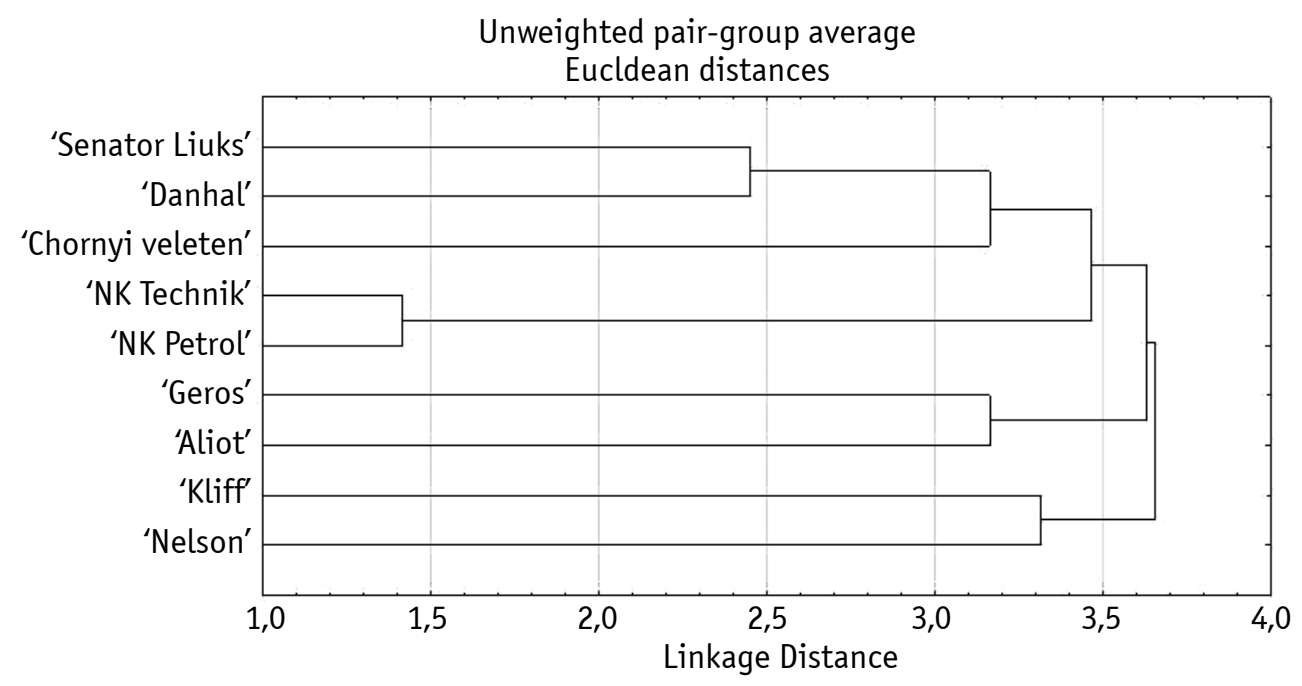

Fig. 4. Cluster analysis of rapeseed varieties by SSR markers

As a result of clustering, four variety clusters emerged: 'Senator Liuks' and 'Danhal', 'NK Technik' and 'NEC Petrol', 'Geros' and 'Aliot', 'Kliff' and 'Nelson'. 'Chornyi Veleten' formed a separate cluster next to 'Senator Liuks' and 'Danhal' varieties. The value of its genetic distances in relation to other varieties was 3.46. Foreign varieties 'NK Technik' and 'NEC Petrol' with the value of genetic distances between them equal 1.41 appeared to be the most similar by the four studied SSR markers.
The most distant varieties included in one cluster were 'Kliff 'and 'Nelson' with a value of 3.32. The highest value of genetic distance (4.00) was recorded between the 'Geros' and 'Kliff' varieties. However, despite the fact these varieties belong to the same type (spring varieties), they considerably differ from each other. However, it should be emphasized that these varieties are the most distant from winter varieties and the value of their genetic distance was 3.74. 
In a research conducted by Tommasini et al. [30], 10 rapeseed varieties were differentiated in terms of type (winter/spring) using a set of 15 markers. The authors found that the SSR markers had the potential to differentiate the varieties of Brassica napus L. and can be used to determine the homogeneity and differences at the initial stage of the DUS-test for the candidate varieties. However, the researchers point out that it is necessary to study and evaluate a larger number of assays and markers to develop a system for their differentiation, not only for testing purpose but also for evaluating the source materials in the breeding process.

We observed a certain differentiation of varieties according to the type of development (winter/spring). However, it should be noted that two clusters were formed by varieties of spring and winter type. The genetic distances between the 'Geros' and 'Aliot', 'Kliff' and 'Nelson' varieties were 3.16 and 3.32 , respectively. Since available research data on the presence of any correlation between the marker and genes responsible for the type of plant development is not sufficient, it can be assumed that the presence or absence of certain allele by the markers under study may be related to the historical aspects of rapeseed breeding. Li et al. [11] differentiated 26 rape varieties using 11 SSR markers and found it more effective to use SSR markers compared to AFLP.

According to the research results, the differentiation of varieties according to their origin was revealed: the varieties of Ukrainian breeding ('Senator Liuks', 'Danhal' and 'Chornyi Veleten') were included in one group of clusters while foreign varieties ('NK Technik', 'Necropolis', 'Geros', 'Kliff' and 'Nelson') in the other one. However, we noted that 'Aliot' variety (Ukrainian) entered the same cluster together with a foreign spring variety. The value of genetic distances between them is 3.16. Such distribution can be explained by the in volvement of genetic plasmas of high-yielding foreign varieties into the breeding process aimed at obtaining varieties with improved agronomic and economic features [31-32].

\section{Conclusions}

The research data on the allele status of microsatellite loci in winter and spring rapeseed varieties of Ukrainian and foreign origin show the polymorphism by the SSR markers Ra3 H09, Na12-A02, FITO-063 and Na10-B07. The level of polymorphism averaged $51 \%$. The number of polymorphic alleles was 24 , which allowed us to differentiate genotypes using the studied markers. The determined genetic dis- tances indicate that the 'Kliff' and 'Nelson' varieties are the most distant from other studied rapeseed varieties with a value of 3.32 . In addition, 'Chornyi Veleten' is attributed to a separate group. The rapeseed varieties differ by at least one marker from each other, indicating the possibility of using a set of markers for their identification. This approach will allow to evaluate the breeding material for selection.

\section{References}

1. Reviron, M. P., Vartanian, N., Sallantin, M., Huet, J. C., Pernollet, J. C., \& de Vienne, D. (1992). Characterization of a novel protein induced by progressive or rapid drought and salinity in Brassica napus leaves. Plant Physiol., 100(3), 1486-1493.

2. Sytnik, I. D., \& Kliachenko, 0. L. (2002). Brassica napus L. in culture in vitro. Ahrarna nauka i osvita [Agrarian Science and Education], 3(3-4), 15-18. [in Ukrainian]

3. Qu, C., Hasan, M., Lu, K., Liu, L., Zhang, K., Fu, F., ... Xu, X. (2015). Identification of QTL for seed coat colour and oil content in Brassica napus by association mapping using SSR markers. Can. J. Plant Sci., 95(2), 387-395. doi: 10.4141/CJPS2013-411

4. Mohammadi, P. P., Moieni, A., \& Komatsu, S. (2012). Comparative proteome analysis of drought-sensitive and drought-tolerant rapeseed roots and their hybrid $\mathrm{F} 1$ line under drought stress. Amino Acids, 43(5), 2137-2152. doi: 10.1007/s00726-012-1299-6

5. Tlili, A., Tarhouni, M., Cerdà, A., Louhaichi, M., \& Neffati, M. (2018). Comparing yield and growth characteristics of four pastoral plant species under two salinity soil levels. Land Degrad. Dev., 29(9), 3104-3111. doi: 10.1002/ldr.3059

6. Munns, R. (2002). Comparative physiology of salt and water stress. Plant Cell Environ., 25(2), 239-250. doi: 10.1046/j.00168025.2001.00808.x

7. Yardanov, I., Velikova, V., \& Tsonev, T. (2003). Plant responses to drought and stress tolerance. Bulg. J. Plant Physiol., Special Issue, 187-206.

8. Lowe, A. J., Moule, C., Trick, M. \& Edwards, K. J. (2004). Efficient large-scale development of microsatellites for marker and mapping applications in Brassica crop species. Theor. Appl. Genet., 108(6), 1103-1112. doi: 10.1007/s00122-003-1522-7

9. Piquemal, J., Cinquin, E., Couton, F., Rondeau, C., Seignoret, E., Perret, D., ... Blanchard, P. (2005). Construction of an oilseed rape (Brassica napus L.) genetic map with SSR markers. Theor. Appl. Genet., 111(8), 1514-1523. doi: 10.1007/s00122-005-0080-6

10. Iniguez-Luy, F. L., Voort, A. V., \& Osborn, T. C. (2008). Development of a set of public SSR markers derived from genomic sequence of a rapid cycling Brassica oleracea L. genotype. Theor. Appl. Genet., 117(6), 977-985. doi: 10.1007/ s00122-008-0837-9

11. Li, L., Wanapu, C., Huang, X., Huang, T., Li, Q., Peng, Y., \& Huang, G. (2011). Comparison of AFLP and SSR for genetic diversity analysis of Brassica napus hybrids. J. Agr. Sci., 3(3), 101-110. doi: 10.5539/jas.v3n3p101

12. Channa, S. A., Tian, H., Wu, H. Q., \& Hu, S. W. (2016). Analysis of genetic diversity among Rapeseed cultivars and breeding lines by SRAP and SSR molecular markers. Pak. J. Bot., 48(6), 2409-2422.

13. Aniskina, Yu. V., Shilov, I. A. \& Havkinm, E. E. (2005). Using the microsatellite polymorphism analysis method to assess the genetic diversity of Brassica forms. In Okruzhayushchaya sreda i zdorov'e: mater. Vseros. nauch.-prakt. konf. molodykh uchenykh $i$ spetsialistov [Environment and Health: Proc. of All-Russian scientific-practical Conf. of young scientists and specialists] (pp. 319-321). May 19-22, 2005, Suzdal, Russian Federation. [in Russian].

14. Geng, J., Javed, N., McVetty, P. B. E., Li, G., \& Tahir, M. (2012). An integrated genetic map for Brassica napus derived from double 
haploid and recombinant inbred populations. Hered. Genet., 1(1), 103. doi: 10.4172/2161-1041.1000103

15. Jamali, S. H., Sadeghi, L., \& Najafian, M. A Multiplex PCR assay for Discriminating Charlock from Rapeseed: Implications for Seed Testing. Biol. Forum Int. J., 9(2), 87-91.

16. Hasan, M., Seyis, F., Badani, A. G., Pons-Kühnemann, J., Friedt, W., Lühs, W., \& Snowdon, R. J. (2006). Analysis of genetic diversity in the Brassica napus L. gene pool using SSR markers. Genet. Resour. Crop Ev., 53(4), 793-802. doi: 10.1007/s10722-0045541-2

17. Youssef, S. S., Moghaieb, R. E., El-Mergawy, R. G., \& El-Sharkawy, A. M. (2006). Genetic markers associated with salt tolerance in canola (Brassica napus L.). Arab. J. Biotech., 10(1), 143-154.

18. Satina, T. G. (2010). Tehnologiya genotipirovaniya na osnove mikrosatellitnogo analiza $v$ selektsii rapsa (Brassica L.) [Genotyping technology based on microsatellite analysis in rapeseed breeding (Brassica L.)] (Extended Abstract of Cand. Biol. Sci. Diss.). All-Russian Research Institute of Agricultural Biotechnology, RAAS, Moscow, Russia [in Russian]

19. Klyachenko, 0., \& Shofolova, N. (2015). Researching of stability of morphogenic and unmorphogenic callus of winter rape (Brassica napus L.) against salt stress. Naukovi dopovidi NUBiP Ukrainy [Scientific reports NULES of Ukraine], 50(1), 1-8.

20. Prysiazhniuk, L. M., Melnyk, S. I., Shytikova, Yu. V., Sihalova, I. 0., \& Ivanytska, A. P. (2017). Application of SSR markers to differentiate new varieties of soybean (Glycine max (L.) Merr.). Plant Var. Stud. Prot., 13(3), 269-276 doi: 10.21498/25181017.13.3.2017.110709 [in Ukrainian]

21. Čurn V., Žaludová, J. (2007). Fingerprinting of oilseed rape cultivars. Adv. Bot. Res., 45, 155-179. doi: 10.1016/s00652296(07)45006-6

22. Li, L. (2010). Characterization of genetic identities and relationships among Brassica napus using AFLP and SSR (Degree of Master of Science in Biotechnology). Suranaree University of Technology, Nakhon Ratchasima, Thailand.

23. Soengas, P., Cartea, M. E., Francisco, M., Lema, M., \& Velasco, P. (2011). Genetic structure and diversity of a collection of Brassica rapa subsp. rapa L. revealed by simple sequence repeat markers. J. Agr. Sci., 149(5), 617-624. doi: 10.1017/ S002185961100013X

24. Wu, W., Zhou, B., Luo, D., Yan, H., Li, Y., \& Kawabata, S. (2012). Development of simple sequence repeat (SSR) markers that are polymorphic between cultivars in Brassica rapa subsp. rapa. Afr. J. Biotechnol., 11(11), 2654-2660. doi: 10.5897/AJB11.3307

25. Tkachyk, S. 0. (Ed.). (2016). Metodyka provedennia kvalifikatsiinoi ekspertyzy sortiv roslyn na prydatnist do poshyrennia $v$ Ukraini. Metody vyznachennia pokaznykiv yakosti produktsii roslynnytstva [Regulations on the procedure and the conduct of qualification tests for suitability of crop varieties for dissemination in Ukraine. Methods of determining quality indices of crop products]. ( $2^{\text {nd }}$ ed., rev.). Vinnytsia: Nilan-LTD. [in Ukrainian]

26. Ermantraut, E. R., Prysiazhniuk, O. I., \& Shevchenko, I. L. (2007). Statystychnyi analiz ahronomichnykh doslidnykh danykh $v$ paketi STATISTICA 6.0 [Statistical analysis of agronomic study data using the Statistica 6.0 software suite]. Kyiv: PolihrafKonsaltynh. [in Ukrainian]

27. Drozdov, V. I. (2010). Instruktsiya po ispolzovaniyu paketa Statistica 6.0 [Manual for using Statistica 6.0]. Kursk: Izd-vo YuZGU. [in Russian]

28. Namorato, H., Miranda, G. V., de Souza, L. V., Oliveira, L. R., DeLima, R. 0., \& Mantovani, E. E. (2009). Comparing Biplot Multivariate Analyses with Eberhart and Russell' method for genotype $\times$ environment interaction. Crop. Breed. Appl. Biot., 9(4), 299-307.

29. Everitt, B. S., Landau, S., Leese, M., \& Stahl, D. (2011). Cluster Analysis. ( $5^{\text {th }}$ ed.). Chichester: John Wiley \& Sons Ltd. doi: 10.1002/9780470977811

30. Tommasini, L., Batley, J., Arnold, G., Cooke, R., Donini, P., Lee, D., ... Edwards, K. (2003). The development of multiplex simple sequence repeat (SSR) markers to complement distinctness, uniformity and stability testing of rape (Brassica napus L.) varieties. Theor. Appl. Genet., 106(6), 1091-1101. doi: 10.1007/s00122-002-1125-8

31. Sytnik, I. D., \& Kliachenko, 0. L. (2010). Screening for source material rape for resistance to abiotic environmental factors. Bioresursy i pryrodokorystuvannia [Biological Resources and Nature Management], 2(1-2), 39-48. [in Ukrainian]

32. Kliachenko, O. L., Sytnik, I. D., \& Halchynska, 0. K. (2012). Ozymyi ta yaryi ripak. Biolohiia. Selektsiia. Biotekhnolohiia [Winter and spring rape. Biology. Selection. Biotechnology]. Kyiv: Fitosotsiotsentr. [in Ukrainian]

\section{Використана література}

1. Reviron M. P., Vartanian N., Sallantin M. et al. Characterization of a novel protein induced by progressive or rapid drought and salinity in Brassica napus leaves. Plant Physiol. 1992. Vol. 100, Iss. 3. P. 1486-1493.

2. Ситнік I. Д., Кляченко 0. Л. Brassica napus L. в культурі in vitro. Аграрна наука і освіта. 2002. Т. 3, № 3-4. С. 15-17.

3. Qu C., Hasan M., Lu K. et al. Identification of QTL for seed coat colour and oil content in Brassica napus by association mapping using SSR markers. Can. J. Plant Sci. 2015. Vol. 95, Iss. 2. P. 387-395. doi: 10.4141/CJPS2013-411

4. Mohammadi P. P., Moieni A., Komatsu S. Comparative proteome analysis of drought-sensitive and drought-tolerant rapeseed roots and their hybrid F1 line under drought stress. Amino Acids. 2012. Vol. 43, Iss. 5. P. 2137-2152. doi: 10.1007/s00726012-1299-6

5. Tlili A., Tarhouni M., Cerdà A. et al. Comparing yield and growth characteristics of four pastoral plant species under two salinity soil levels. Land Degrad. Dev. 2018. Vol. 29, Iss. 9. P. 3104-3111. doi: 10.1002/ldr.3059

6. Munns R. Comparative physiology of salt and water stress. Plant Cell Environ. 2002. Vol. 25, Iss. 2. P. 239-250. doi: 10.1046/ j.0016-8025.2001.00808.x

7. Yardanov I., Velikova V., Tsonev T. Plant responses to drought and stress tolerance. Bulg. J. Plant Physiol. 2003. Special Issue. P. 187-206.

8. Lowe A. J., Moule C., Trick M., Edwards K. J. Efficient large-scale development of microsatellites for marker and mapping applications in Brassica crop species. Theor. Appl. Genet. 2004. Vol. 108, Iss. 6. P. 1103-1112. doi: 10.1007/s00122-003-1522-7

9. Piquemal J., Cinquin E., Couton F. et al. Construction of an oilseed rape (Brassica napus L.) genetic map with SSR markers. Theor. Appl. Genet. 2005. Vol. 111, Iss. 8. P. 1514-1523. doi: 10.1007/s00122-005-0080-6

10. Iniguez-Luy F. L., Voort A. V., Osborn T. C. Development of a set of public SSR markers derived from genomic sequence of a rapid cycling Brassica oleracea L. genotype. Theor. Appl. Genet. 2008. Vol. 117, Iss. 6. P. 977-985. doi: 10.1007/s00122-0080837-9

11. Li L., Wanapu C., Huang X. et al. Comparison of AFLP and SSR for genetic diversity analysis of Brassica napus hybrids. J. Agr. Sci. 2011. Vol. 3, Iss. 3. P. 101-110. doi: 10.5539/jas.v3n3p101

12. Channa S. A., Tian H., Wu H. Q., Hu S. W. Analysis of genetic diversity among Rapeseed cultivars and breeding lines by SRAP and SSR molecular markers. Pak. J. Bot. 2016. Vol. 48, Iss. 6. P. 2409-2422.

13. Анискина Ю. В., Шилов И. А., Хавкин Э. Е Использование метода анализа полиморфизма микросателлитов для оценки генетического разнообразия форм Brassica. Окружающая среда и здоровье : матер. Всерос. науч.-практ. конф. молодых ученых и специалистов (г. Суздаль, 19-22 мая 2005 г.). Суздаль, 2005. С. 319-321.

14. Geng J., Javed N., McVetty P. B. E. et al. An integrated genetic map for Brassica napus derived from double haploid and recombinant inbred populations. Hered. Genet. 2012. Vol. 1, Iss. 1. P. 103. doi: 10.4172/2161-1041.1000103 
15. Jamali S. H., Sadeghi L., Najafian M. A Multiplex PCR assay for Discriminating Charlock from Rapeseed: Implications for Seed Testing. Biol. Forum Int. J. 2017. Vol. 9, Iss. 2. P. 87-91.

16. Hasan M., Seyis F., Badani A. G. et al. Analysis of genetic diversity in the Brassica napus L. gene pool using SSR markers. Genet. Resour. Crop Ev. 2006. Vol. 53, Iss. 4. P. 793-802. doi: 10.1007/s10722-004-5541-2

17. Youssef S. S., Moghaieb R. E., El-Mergawy R. G., El-Sharkawy A. M. Genetic markers associated with salt tolerance in canola (Brassica napus L.). Arab. J. Biotech. 2006. Vol. 10, Iss. 1. P. 143-154.

18. Сатина Т. Г. Технология генотипирования на основе микросателлитного анализа в селекции рапса (Brassica L.) : автореф. дис. ... канд. биол. наук : спец. 03.01.06 «Биотехнология» / Всерос. НИИ с.-х. биотехнологии. Москва, 2010. 21 с.

19. Кляченко 0. Л., Шофолова Н.В.Дослідження стійкості морфогенного і неморфогенного калюсу озимого ріпаку (Brassica napus L.) проти сольового стресу. Наукові доповіді НУБіП України. 2015. Т. 50, № 1. С. 1-8. URL: http://journals. uran.ua/index.php/2223-1609/article/view/116945/111011

20. Присяжнюк Л. М., Мельник С. І., Шитікова Ю. В. та ін. Використання SSR-маркерів для диференціації нових сортів сої (Glycine max (L.) Merr.). Plant Var. Stud. Prot. 2017. T. 13, № 3. C. 269-276. doi: 10.21498/2518-1017.13.3.2017.110709

21. Čurn V., Žaludová J. Fingerprinting of oilseed rape cultivars. Adv. Bot. Res. 2007. Vol. 45. P. 155-179. doi: 10.1016/s00652296(07)45006-6

22. Li L. Characterization of genetic identities and relationships among brassica napus using AFLP and SSR : Degree of Master of Science in Biotechnology / Suranaree University of Technology, Nakhon Ratchasima, Thailand, 2010. 129 p.

23. Soengas P., Cartea M. E., Francisco M. et al. Genetic structure and diversity of a collection of Brassica rapa subsp. rapa $\mathrm{L}$. revealed by simple sequence repeat markers. J. Agr. Sci. 2011. Vol. 149, Iss. 5. P. 617-624. doi: 10.1017/S002185961100013X
24. Wu W., Zhou B., Luo D. et al. Development of simple sequence repeat (SSR) markers that are polymorphic between cultivars in Brassica rapa subsp. rapa. Afr. J. Biotechnol. 2012. Vol. 11, Iss. 11. P. 2654-2660. doi: 10.5897/AJB11.3307

25. Методика проведення кваліфікаційної експертизи сортів рослин на придатність до поширення в Україні. Методи визначення показників якості продукції рослинництва / за ред. С. О. Ткачик. 2-ге вид., випр. и доп. Вінниця : Нілан-лтД, 2016. 160 c.

26. Ермантраут Е. Р. Присяжнюк 0. І., Шевченко I. Л. Статистичний аналіз агрономічних дослідних даних в пакеті STATISTICA 6.0. Київ : ПоліграфКонсалтинг, 2007. 55 с.

27. Дроздов В. И. Инструкция по использованию пакета Statistica 6.0. Курск : Изд-во ЮзГУ, 2010. 74 с.

28. Namorato H., Miranda G. V., de Souza L. V. et al. Comparing Biplot Multivariate Analyses with Eberhart and Russell' method for genotype $\times$ environment interaction. Crop. Breed. Appl. Biot. 2009. Vol. 9, Iss. 4. P. 299-307.

29. Everitt B. S., Landau S., Leese M., Stahl D. Cluster Analysis. $5^{\text {th }}$ ed. Chichester : John Wiley \& Sons Ltd, 2011. 346 p. doi: 10.1002/9780470977811

30. Tommasini L., Batley J., Arnold G. et al. The development of multiplex simple sequence repeat (SSR) markers to complement distinctness, uniformity and stability testing of rape (Brassica napus L.) varieties. Theor. Appl. Genet. 2003. Vol. 106, Iss. 6. P. 1091-1101. doi: 10.1007/s00122-002-1125-8

31. Ситнік І. Д., Кляченко 0. Л. Скринінг вихідного матеріалу ріпаку на стійкість до абіотичних факторів навколишнього середовища. Біоресурси і природокористування. 2010. Т. 2, № $1 / 2$. С. 39-48.

32. Кляченко 0. Л., Ситник І. Д., Гальчинська 0. К. Озимий та ярий ріпак. Біологія. Селекція. Біотехнологія. Київ : Фітосоціоцентр, 2012. 244 с.

\section{УДК 633.853.494.577.213.3}

Кляченко О. Л. ${ }^{1}$, Присяжнюк Л. М. ${ }^{2 *}$, Шофолова Н. В. ${ }^{1}$, Піскова О. В. ${ }^{2}$ Поліморфізм сортів ріпаку озимого та ярого (Brassica napus L.) за SSR маркерами. Plant Varieties Studying and Protection. 2018. T. 14, № 4. C. 366-374. https://doi.org/10.21498/2518-1017.14.4.2018.151898

${ }^{1}$ Національний університет біоресурсів і природокористування України, вул. Героїв Оборони, 15, м. Київ, 03041, Україна

гукраїнський інститут експертизи сортів рослин, вул. Генерала Родимцева, 15, м. Київ, 03041, Україна, ”e-mail: prysiazhniuk_l@ukr.net

Мета. Оцінити генетичне різноманіття сортів ріпаку за допомогою SSR-маркерів для створення селекційного матеріалу із застосуванням його в комплексній селекції in vitro на посухо- та солестійкість. Методи. ПЛР аналіз, кластерний аналіз. Результати. Наведено результати досліджень поліморфізму сортів ріпаку на основі молекулярно-генетичних маркерів. У результати аналізу сортів ріпаку за досліджуваними маркерами виявили 41 алель, тобто в середньому 10,3 алелі на маркер. Кількість поліморфних локусів за чотирма мікросателітними маркерами (Ra3-H09, Na12-A02, FITO-063 та Na10-B07) складала 24 локуси. Рівень поліморфізму для досліджуваних сортів у середньому становив 51\%: найвищий рівень $(87 \%)$ відмічений для маркера Na12-A02, найнижчий (33\%) - FITO-063. Відповідно до отриманого розподілу найбільшою частотою за SSR маркером Ra3-H09 вирізнялась алель розміром 117 п.н., яку ідентифіковано у трьох сортів: 'Сенатор Люкс', 'Дангал' та 'Чорний велетень'. Виявлено, що за маркером Ra3-H09 унікальним для досліджуваних сортів виявились алелі з частотою 0,06 та розмірами 135 п.н. у сорту 'Аліот' та 156 п.н. у сорту 'Кліфф'. За маркером FIT0-063 ідентифіковано найменшу кількість алелів (5), при цьому розподіл частот варіював від 0,11 до 0,33. Унікальними алелями за маркером
FIT0-063 виявились алелі розміром 258 та 273 п.н. $з$ частотою 0,11 у сортів 'Герос' та 'Чорний велетень' відповідно. Найбільшу кількість алелів було отримано за допомогою маркеру Na12-A02. Відповідно до отриманого розподілу найбільше значення частоти $(0,11)$ мали алелі розміром 158 та 192 п.н. За маркером Na10-B07 з частотою 0,04 було ідентифіковано три алеля. Вказані алелі розмірами 144, 156 та 194 п.н. виявили у сортів 'Кліфф', 'Герос' та 'Нельсон'. У результаті кластерного аналізу отримано чотири кластери: 'Сенатор Люкс' та 'Дангал', 'НК Технік' та 'НК Петрол', 'Герос' та 'Аліот', 'Кліфф' та 'Нельсон'. Відмічено, що сорт 'Чорний велетень' не належить до жодного кластеру. Встановлено, що найбільш віддаленими виявились сорти 'Кліфф' та 'Нельсон' із значенням генетичних дистанцій 3.32. Найбільш подібними за чотирма досліджуваними SSR маркерами виявились сорти іноземної селекції 'НК Технік' та 'НК Петрол' зі значенням генетичних дистанцій між ними 1.41. Інші сорти мають відмінності за щонайменше одним маркером. Висновки. Застосування системи із чотирьох мікросателітних маркерів забезпечує оцінку сортового різноманіття ріпаку для комплексної селекції in vitro на посухо- та солестійкість.

Ключові слова: сортове різноманіття; ріпак; мікросателітні маркери; кластерний аналіз. 
УДК 633.853.494.577.213.3

Кляченко 0. Л. ${ }^{1}$, Присяжнюк Л. М. ${ }^{2 *}$, Шофолова Н. В. ${ }^{1}$, Писковая О. В. ${ }^{2}$ Полиморфизм сортов рапса озимого и ярового (Brassica napus L.) по SSR маркерам // Plant Varieties Studying and Protection. 2018. T. 14, № 4. C. 366-374. https://doi.org/10.21498/2518-1017.14.4.2018.151898

${ }^{1}$ Национальный университет биоресурсов и природопользования Украины, ул. Героев 0бороны, 15, г. Киев, 03041, Украина гукраинский институт экспертизы сортов растений, ул. Генерала Родимцева, 15, г. Киев, 03041, Украuна, ”e-mail: prysiazhniuk_l@ukr.net

Цель. Оценить генетическое разнообразие сортов рапса с помощью SSR маркеров для создания селекционного материала с применением его в комплексной селекции in vitro на засухо- и солеустойчивость. Методы. ПЦР анализ, кластерный анализ. Результаты. Приведены результаты исследований полиморфизма сортов рапса на основе молекулярно-генетических маркеров. В результате анализа сортов рапса по испытуемым маркерам обнаружили 41 аллель, то есть в среднем 10,3 аллелей на маркер. Количество полиморфных локусов по четырем микросателитным маркерам (Ra3-H09, Na12-A02, FIT0-063 и Na10-B07) составляло 24 локуса. Уровень полиморфизма изучаемых сортов в среднем составляет 51\%: самый высокий уровень (87\%) отмечен для маркера Na12-A02, самый низкий (33\%) - FITO-063. В соответствии с полученным распределением наибольшей частотой по SSR маркеру Ra3-H09 отличалась аллель размером 117 п.н., которую идентифицировано у трех сортов: 'Сенатор Люкс', 'Дангал' и 'Черный велетень'. Выявлено, что по маркеру Ra3-H09 уникальным для изучаемых сортов оказались аллели с частотой 0,06 и размерами 135 п.н. у сорта 'Алиот' и 156 п.н. у сорта 'Клифф'. По маркеру FIT0-063 идентифицировано наименьшее количество аллелей (5), при этом распределение частот варьировало от 0,11 до 0,33. Уникальными аллелями по маркеру FITO-063 оказались аллели разме- ром 258 и 273 п.н. с частотой 0,11 у сортов 'Герос' и 'Черный велетень' соответственно. Наибольшее количество аллелей было получено с помощью маркера Na12-A02. B соответствии с полученным распределением наибольшее значение частоты $(0,11)$ было у аллелей размером 158 и 192 п.н. По маркеру Na10-B07 с частотой 0,04 было идентифицировано три аллеля. Указанные аллели размерами 144, 156 и 194 п.н. обнаружили у сортов 'Клифф', 'Герос' и 'Нельсон'. В результате кластерного анализа получено четыре кластера: 'Сенатор Люкс' и 'Дангал', 'НК Техник' и 'НК Петрол', 'Герос' и 'Алиот', 'Клифф' и 'Нельсон'. Отмечено, что сорт 'Черный велетень' не принадлежит ни к одному кластеру. Установлено, что наиболее удаленными оказались сорта 'Клифф' и 'Нельсон' со значением генетических дистанций 3.32. Наиболее подобными по четырем исследуемыми SSR маркерами оказались сорта иностранной селекции 'НК Техник' и 'НК Петрол' со значением генетических дистанций между ними 1.41. Другие сорта имеют различия по крайней мере по одному маркеру. Выводы. Таким образом, применение системы из четырех микросателлитных маркеров обеспечивает оценку сортового разнообразия рапса для комплексной селекции in vitro на засухо- и солеустойчивость.

Ключевые слова: сортовое разнообразие; рапс; микросателлитные маркеры; кластерный анализ.

Надійшла / Received 26.10.2018

Погоджено до друку / Accepted 11.12.2018 